\title{
Editorial
}

\section{Plan or Be Planned for: The Growing Significance of Strategic Planning}

Since the mid-1960s, corporate leaders have been using strategic planning as the "one best way" to design, create, and realize their organizations' future. By the beginning of the 1980s, we began witnessing the use of strategic planning by many nonprofit organizations including churches, schools, and different types of libraries. Unlike traditional planning, strategic planning is ongoing and iterative, involves the development of cognition, and is a learning process. Moreover, its emphasis on the formulation of strategies (courses of action to achieve goals and objectives) sets it far apart and ahead of any other planning technique.

During the early 1990s, we began seeing some pieces in the literature about the weaknesses/failures of strategic planning. I have heard/read comments about strategic planning no longer being relevant during our exponential rate of change in libraries. When the adversaries are questioned about what planning alternative they would offer in place of strategic planning, they cannot give any. One hears comments such as "total quality management and reengineering are better planning mechanisms than strategic planning." When I hear such comments, I tend to bite my tongue and not speak what is on my mind. Total quality management and reengineering are not planning tools! They focus on current procedures and processes, not on the future. Both techniques offer much in the way of improving the way libraries are run and the services they provide. When I hear librarians beating up on TQM or reengineering, I ask one

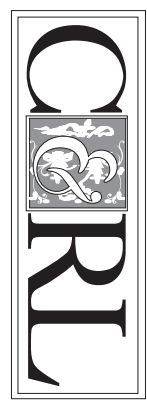
simple question: Who can argue with continuous improvement?

For some unknown reasons, many library leaders and managers do not possess an understanding of leadership and management principles and practices. They prefer to lead/manage in an ad hoc, chaotic, or "by the seat of pants" approach. One former library director of a major research library told me that he would never develop any formal plan due to his preference for keeping the library staff confused. Rather than developing a strategic plan that will help the library identify and maintain an optimal alignment with the most important elements of its environment, some library leaders prefer to give flippant, unsubstantiated reasons why strategic planning will not work. I surmise that such leaders probably do not have the faintest idea what strategic planning really is. People generally do not like planning; they prefer action whether or not it is based on analysis and synthesis.

There is a tendency to describe strategic planning as being inflexible, stuck in concrete, and not nimble enough for the changing environment of libraries. Again, such descriptions generally come from people who do not fully understand strategic planning. The genesis of strategic planning dates back to its use in the military. Can anyone imagine a military unit using a planning technique that does not include flexibility, redirection, and modification in the heat of battle? Of course, we will continue to know people who prefer to operate from 
happenstance, not knowing where they are beginning and where they are heading.

When I was teaching the advanced management for libraries and information agencies course at the University of Michigan's School of Information, students in my class delved deeply into the components of strategic planning. They examined the weaknesses and strengths of this particular planning process. Among other things, they discovered that good strategic actions are largely a matter of feel, intuition, artistry, and luck. Also, they concluded that a sharp analysis of strategies contributes little to the synthetic moves of the successful strategist.

Human nature and inertia favor the old way of doing things. Shaping change must happen more quickly than ever before in libraries. Performing a major strategic transformation without much forethought and involvement of the library can certainly backfire and result in serious impairment of the credibility of library managers. "Ready, fire, aim" usually results in unnecessary commotion and counterproductivity. Certainly, as the tempo of change increases and the complexity of life accelerates, the future of libraries can be cruel and unforgiving. The future of libraries need not be the dark world of the unknown.

The heart of strategic thinking and planning is the creation of a set of initiatives allowing an organization to maintain stability or win a new position amidst a blizzard of discontinuities, unprecedented threats, and surprising changes. ${ }^{1}$ The rate of change in libraries is expected to quicken; library managers cannot just respond to change but, rather, must drive it. If the strategic planning process is carried out to its fullest extent, most of the library's staff will have some involvement in the creation and implementation of strategies. Real strategists get their hands dirty digging for ideas, and real strategies are built from the occasional nuggets they uncover. $^{2}$ Some of the best thinking opportunities for the library staff occur while they are developing strategies. Real strategic change in libraries requires inventing new ways of doing things, not simply rearranging existing things.

The strategic plan should be viewed as a working document; it is never completed, and it certainly has to undergo a rigorous updating/refinement on a regular basis. If the strategic planning process is done properly, the participants may find the process (e.g, conducting the environmental scan, determining strengths and weaknesses, and formulating strategies) as useful as the document itself.

Recent management and higher education literature contains several works focusing on strategic planning and its utility during the change process. Notwithstanding the many fallacies of strategic planning, it remains the best planning tool. It is particularly suited for libraries and institutions of higher education. For today's colleges and universities, no longer immune from the world in which they live, strategic planning can be a logical and effective method of intervention, defining an appropriate direction toward a future in which they will flourish. ${ }^{3}$

\section{DONALD E. RIGGS}

\section{Notes}

1. Marvin W. Peterson, et al., Planning and Management for a Changing Environment (San Francisco: Jossey-Bass, 1997), 160.

2. Henry Mintzberg, "The Fall and Rise of Strategic Planning," Harvard Business Review 72 (Jan.-Feb. 1994): 107-14.

3. Daniel J. Rowley, et al., Strategic Change in Colleges and Universities (San Francisco: Jossey-Bass, 1997), 320. 